Research Article

\title{
Comparative analysis of national essential medicine list for children by Indian academy of pediatrics and pediatric drugs available at a tertiary care teaching hospital in Rajkot, Gujarat, India
}

\author{
Mitalee Prajapati $^{1}$, Amita Kubavat ${ }^{1}$, Nishant Bhansali ${ }^{2}$
}

\begin{abstract}
${ }^{1}$ Department of Pharmacology, P. D. U. Government Medical College, Rajkot, Gujarat, India ${ }^{2}$ Department of Pharmacology, M. P. Shah Government. Medical College, Jamnagar, Gujarat, India
\end{abstract}

Received: 10 July 2016

Revised: 12 July 2016

Accepted: 09 August 2016

*Correspondence to:

Dr. Mitalee Prajapati,

Email: mitaleeprajapati@ gmail.com

Copyright: (๑) the author(s), publisher and licensee Medip Academy. This is an openaccess article distributed under the terms of the Creative Commons Attribution NonCommercial License, which permits unrestricted noncommercial use, distribution, and reproduction in any medium, provided the original work is properly cited.

\begin{abstract}
Background: The better medicines for children initiative of the WHO began in December 2007 as a consequence of the World Health Assembly resolution 60.20 , when there was evidence that nearly $50 \%$ of children under five were dying for preventable diseases for which medicines existed. There is a need to develop "child friendly" formulations and make them available.

Methods: This cross sectional study was conducted during September 2015. The availability of essential medicine for children (drugs, strength, and dosage form) was noted down. Drugs which are not listed in the National list of Essential medicines (NLEMc) for children but available in the hospital pharmacy were also noted down.

Results: Out of the drugs listed in NLEMc, 86.56\% drugs were available in the pharmacy of tertiary care teaching hospital, Rajkot. $57.76 \%$ percent of these drug formulations were available as specified in NLEMc and $44.36 \%$ of the available drugs had the same strength as specified in NLEMc. For those drugs which are mentioned in NLEMc but not available in the hospital pharmacy, alternative drugs are available for the same indication.

Conclusions: Majority of the drugs available in hospital pharmacy of tertiary care teaching hospital, Rajkot are in accordance to NLEMc. However hospital pharmacy is deficient in paediatric formulations and strength in accordance to NLEMc.
\end{abstract}

Keywords: Children, NLEMc, IAP

\section{INTRODUCTION}

WHO "levels and trends in child mortality 2014" show that 6.3 million children under the age of five years died in 2013. Among these most of these early child deaths could be prevented. India $(21 \%)$ and Nigeria (13\%) together account for more than one third of under five children death. ${ }^{1}$

Pediatric population is heterogeneous group with different age groups with different physiologic and development stages. The availability of pediatric formulations and strengths are limited due to higher cost, limited demand and require specific storage conditions. ${ }^{2}$ To increase the global awareness of essential medicines for children WHO initiated "better medicines for children initiative" and "make medicine child size" campaign. ${ }^{3}$ Four editions of essential medicine list for the children (up to 12 years of age) were published by WHO. Latest edition was on April 2013. ${ }^{4}$

The concept of child friendly formulations is at infant stage. Indian academy of paediatrics (IAP) published national essential medicine list for children (NEMLc) on 
October 2011based upon WHO criteria of selection list and national health programs. ${ }^{5}$ Chhattisgarh and Odisha are the only two states included paediatric specific formulations in their essential medicines in their EML. Even $7-17 \%$ paediatric formulations only procured.

\section{METHODS}

Observational cross sectional study was done at pharmacy of tertiary care teaching hospital Rajkot. Existing hospital Pediatric medicine list was obtained from central medical store along their dosage forms and strengths. IAP - NEMLc October 2011 was downloaded from the official website and was used as reference for comparison. The percentage availability of the medicines along with dosage forms, strengths present in hospital were noted at the time of visit and the reason of nonavailability.

\section{RESULTS}

NEMLc contain 134 drugs including fixed dose combinations. They are 22 groups including cardiovascular, CNS, oncologic, analgesic, anti-allergic, and ophthalmic, ENT, dermatological drugs. Hospital pharmacy contains 116 drugs (at least single dose) (86.56\%). As per utility analysis hospital pharmacy maintains most of the drugs. The drugs not available in the hospital pharmacy listed in Table 1 .

Table 1: List of drugs not available in hospital pharmacy from NLEMc.

\begin{tabular}{|ll|}
\hline Drugs not available at hospital & Group of drug \\
\hline Morphine & Opioid analgesic \\
\hline Charcoal activated & Antidote \\
\hline Naloxone & Antidote \\
\hline Pentamidine isothionate & Antileishmaniasis \\
\hline Sod. Stibogluconate & Antileishmaniasis \\
\hline Hydroxyurea & Antianaemia \\
\hline Levothyroxine & Thyroid hormone \\
\hline Pyrantel & Anti-helminthic \\
\hline Abacavir & Anti-HIV \\
\hline Didanosine & Anti-HIV \\
\hline Lamivudine & Anti-HIV \\
\hline Zidovudine & Anti-HIV \\
\hline Daunorubicin & Anticancer \\
\hline Mercaptopurine & Anticancer \\
\hline Methotraxate & Anticancer \\
\hline Methylprednisolone & Anticancer \\
\hline Chloroxylenol & Disinfectants \\
\hline $\begin{array}{l}\text { Insulin (insulin zinc or isophane } \\
\text { insulin) }\end{array}$ & Hormones \\
\hline Procaine benzyl penicillin & Antibiotics \\
\hline
\end{tabular}

NLEMc contains 284 dosage strengths for children less than 12 years of old. Hospital pharmacy contains 126 dosage strengths.

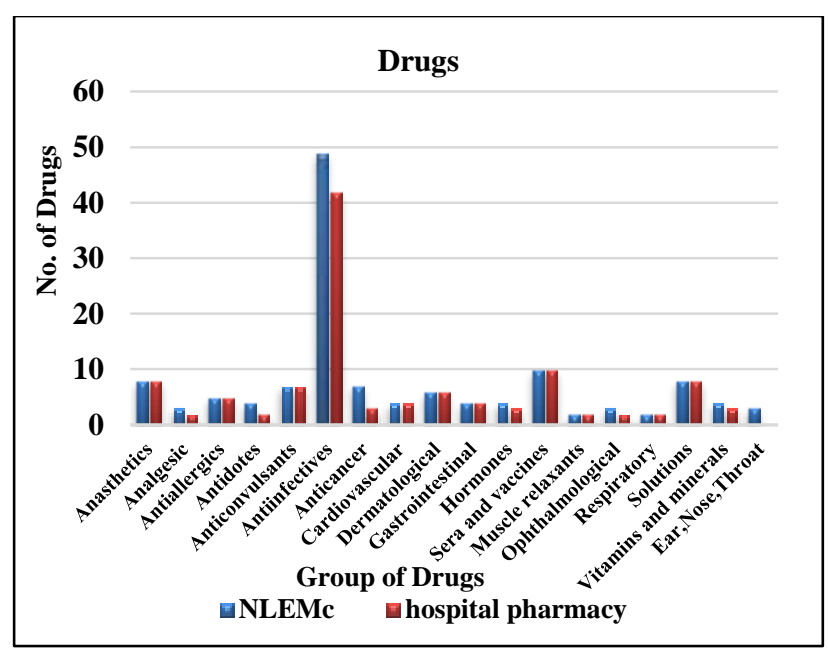

Figure 1: Comparison of drugs available at hospital pharmacy from NLEMc.

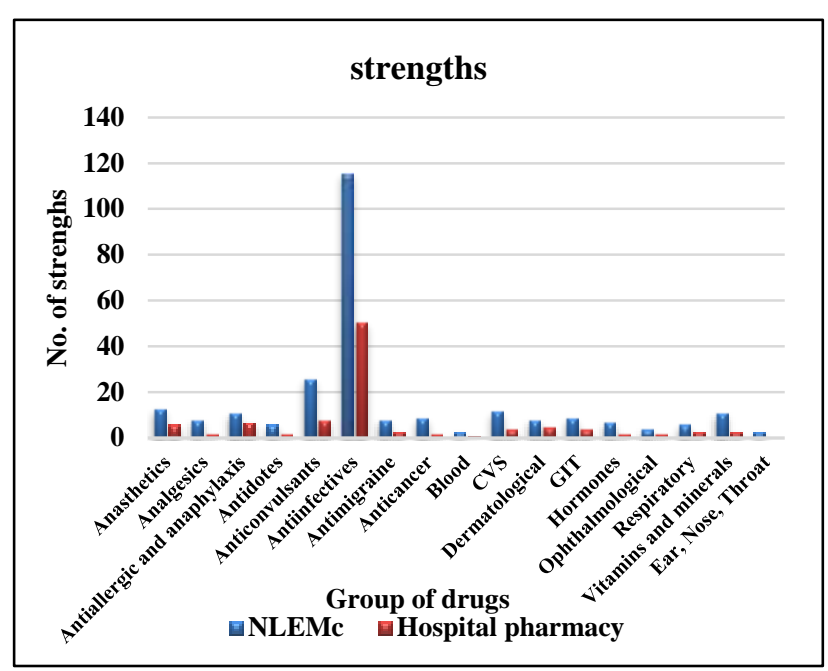

Figure 2: Comparison of strengths available at hospital pharmacy from NLEMc.

The dosage forms commonly missing from hospital pharmacy given in Table 2. Mainly chewable, dispersible tablet, dental cartridge, oral liquids are missing.

Table 2: List of the dosage formulations missing from hospital pharmacy.

\begin{tabular}{|c|c|}
\hline Group of the drug & Formulations not available \\
\hline Local anaesthetics & $\begin{array}{l}\text { Lidocaine + epinephrine } \\
\text { (dental cartridge) }\end{array}$ \\
\hline $\begin{array}{l}\text { Sedation for short } \\
\text { term procedure }\end{array}$ & Midazolam (oral liquid) \\
\hline $\begin{array}{l}\text { Antiallergics and } \\
\text { medicine used in } \\
\text { anaphylaxis }\end{array}$ & $\begin{array}{l}\text { Chlorphenamine (oral liquid), } \\
\text { prednisolone (oral liquid) }\end{array}$ \\
\hline Antiepilepticts & $\begin{array}{l}\text { Carbamazepine (oral liquid, chewable } \\
\text { tablet), phenobarbital (oral liquid), } \\
\text { phenytoin (oral liquid, chewable } \\
\text { tablet), sodium valproate (oral liquid, } \\
\text { crushable tablet) }\end{array}$ \\
\hline Antifilariasis & Diehylcarbamazine (oral liquid) \\
\hline
\end{tabular}




\begin{tabular}{|ll|}
\hline $\begin{array}{l}\text { Betalactum } \\
\text { antibiotics }\end{array}$ & $\begin{array}{l}\text { Amoxicillin+ clavulanic acid (oral } \\
\text { liquid, dispersible tablet), Cefadroxil } \\
\text { (powder for oral liquid), procaine } \\
\text { benzyl penicillin(powder for } \\
\text { injection) }\end{array}$ \\
\hline Other antibacterials & $\begin{array}{l}\text { Ciprofloxacin (oral liquid, dispersible } \\
\text { tablet), sulfamethoxazole + } \\
\text { trimethoprim (injection) }\end{array}$ \\
\hline Antileprosy drugs & Rifampicin (oral liquid) \\
\hline $\begin{array}{l}\text { Antituberculosis } \\
\text { drugs }\end{array}$ & $\begin{array}{l}\text { Isoniazid (oral liquid), pyrazinamide } \\
\text { (oral liquid), rifampicin (oral liquid) }\end{array}$ \\
\hline Antifungal drugs & Fluconazole (oral liquid, injection) \\
\hline Antiretroviral drugs & $\begin{array}{l}\text { Efavirenz (oral liquid, capsule), } \\
\text { nevirapine (oral liquid) }\end{array}$ \\
\hline Antimalarial drugs & Quinine (suspension) \\
\hline Antianaemia drugs & $\begin{array}{l}\text { Ferrous sulphate + folic acid (oral } \\
\text { liquid) }\end{array}$ \\
\hline $\begin{array}{l}\text { Cardiovascular } \\
\text { medicines }\end{array}$ & $\begin{array}{l}\text { Digoxin (oral liquid), } \\
\text { furosemide (oral liquid), } \\
\text { spironolactone (oral liquid) }\end{array}$ \\
\hline $\begin{array}{l}\text { Dermatological } \\
\text { medicines }\end{array}$ & Hydrocortisone (cream or ointment) \\
\hline $\begin{array}{l}\text { Gastrointestinal } \\
\text { medicines }\end{array}$ & $\begin{array}{l}\text { Metoclopramide (oral liquid), } \\
\text { omeprazole (granules for oral liquids) }\end{array}$ \\
\hline $\begin{array}{l}\text { Ophthalmic } \\
\text { preparation }\end{array}$ & Atropine (ointment) \\
\hline $\begin{array}{l}\text { Ear, nose and throat } \\
\text { preparation }\end{array}$ & $\begin{array}{l}\text { Budesonide (nasal sprays), } \\
\text { xylometazoline (nasal drops) }\end{array}$ \\
\hline
\end{tabular}

Table 3 shows alternative drugs available in hospital pharmacy for those drugs that are missing according to NLEMc.

Table 3: List of alternative drugs available in hospital pharmacy that are not mentioned in NLEMc.

\begin{tabular}{|ll|}
\hline Group of the drug & Alternative drugs available \\
\hline Antileishmaniasis & Amphotericin B \\
\hline Antianaemic & Iron + folic acid \\
\hline Antihelminthics & Albendazole \\
\hline Anti HIV & Combinations are available \\
\hline Anticancer & $\begin{array}{l}\text { Etoposide, fosaprepitant, fluorouracil } \\
\text { granicet, gemcitabine, interferon, } \\
\text { leucoverin, paclitaxel, zolidronic acid } \\
\text { bleonycin, cisplatine, doxorubicin. }\end{array}$ \\
\hline
\end{tabular}

\section{DISCUSSION}

Pharmacologically children make a heterogeneous group with different pharmacokinetics from that of adults. Particularly Infants and new born must need specific medicines in correct and appropriate dosage formulations and strength as they suffer from different disease than adults. Our study demonstrated that $86.56 \%$ availability of paediatric medicines and modest scarcity of formulations and strength in tertiary care teaching hospital, Rajkot

The drugs not available in the pharmacy are pyrantel, diloxanide, sodium stibogluconate, pentamidine isothionate, daunorubicin, mercaptopurine, naloxone, hydroxyurea, morphine, activated charcoal. Alternative drugs like albendazole, Metronidazole, fluconazole, and amphotericin B are available. Etoposide, fosaprepitant, fluorouracil, granicet, gemcitabine, interferon, leucoverin, paclitaxel, zolidronic acid, bleonycin, cisplatine, and doxorubicin are the alternative anti-cancer drugs available in hospital. Anti-HIV drugs combinations are available. ${ }^{4,5}$

Regarding formulations paediatric specific like dispersible, chewable formulations are completely absent. Formulations mentioned in the IAP- Essential medicine list for children October 2011 only $57.76 \%$ are available. Only $44.36 \%$ paediatric specific strength is available in the hospital. For paediatric use adult dosage forms are grinded or divided by health care workers or parents. Paediatric specific formulations are worldwide concern for which WHO initiated campaign like "make medicines child size" and "child friendly formulations" to increase the awareness of paediatric specific strength and formulations.

\section{Funding: No funding sources \\ Conflict of interest: None declared \\ Ethical approval: Not required}

\section{REFERENCES}

1. Child mortality estimates. Available at http://www.who.int/medicacentre/news/releases/2014 Accessed on 9 October 2014.

2. Gitanjali B. Essential medicines for children: should we focus on priority list of medicines for the present? J Pharmacol Pharmacotherapeutics. 2011;2:1-2.

3. Better medicines for the children project. Overview of methods for medicines availability and pricing surveys, 2009. Available at http://www.who.int/childmedicines/progress/ChildM eds_pricing_surveys.pdf. Accessed on 16 August 2014.

4. WHO model list of essential medicines for Children. Available at http://www.who.int/medicines/publications/essential medicines/en/index.html.

5. Indian academy of pediatrics list of essential medicines for children of India, 2011. Available at http://apps.who.int/medicinedocs/en/d/Js19040en/.

Cite this article as: Prajapati M, Kubavat A, Bhansali N. Comparative analysis of national essential medicine list for children by Indian academy of pediatrics and pediatric drugs available at a tertiary care teaching hospital in Rajkot, Gujarat, India. Int J Basic Clin Pharmacol 2016;5:2077-9. 